OPEN ACCESS

Edited by:

Adam Burnett,

Colgate University, United States

Reviewed by:

Scott Robeson,

Indiana University, United States

Trent Ford,

University of lllinois a

Urbana-Champaign, United States

*Correspondence: Matthew L. Trumper

trump022@umn.edu

Specialty section:

This article was submitted to

Water and Climate,

a section of the journal

Frontiers in Water

Received: 25 October 2021 Accepted: 20 December 2021

Published: 25 January 2022

Citation:

Trumper ML, Griffin D, Montpellier EE and Kipfmueller KF (2022) Pinus

resinosa Tree-Ring Latewood Response to Daily-Scale Precipitation Variability at Lake Itasca, Minnesota.

Front. Water 3:801265

doi: 10.3389/frwa.2021.801265

\section{Pinus resinosa Tree-Ring Latewood Response to Daily-Scale Precipitation Variability at Lake Itasca, Minnesota}

\author{
Matthew L. Trumper*, Daniel Griffin, Evan E. Montpellier and Kurt F. Kipfmueller \\ Department of Geography, Environment, and Society, University of Minnesota, Minneapolis, MN, United States
}

Analysis of daily scale climate observations alongside sub-annual tree-ring data offers new potential for contextualizing climate change in the Great Lakes region. This pilot study combined daily observations from a high-quality station record with a co-located chronology of Pinus resinosa latewood width at Lake Itasca, Minnesota. We evaluate trends in observational data and use multiple methods to compare day-wise aggregated climate observations with tree rings over the eleven-decade common period. The Itasca record exhibited strong increases in warm-season precipitation, minimum temperature in all seasons, and lengthening of the freeze-free season. Correlation analyses verified a strong, multi-month warm-season precipitation response in Pinus resinosa latewood width. Distinct from previous work, daily data analyses were used to fingerprint an $\sim 2$-week period starting in late July when rainfall variability was historically a major control on interannual tree growth. Climatologically, the timing of this subseasonal critical climate period corresponds with a relative minimum in mean midsummer precipitation. Since the 1980s, the latewood correlation with midsummer rainfall has vanished, and the seasonal-scale rainfall response diminished considerably. This result, new for Pinus resinosa in Minnesota, is consistent with studies showing a declining relationship between tree growth and drought in the Midwest United States. Further attribution analyses emphasizing daily-scale phenomena are needed to elucidate mechanisms responsible for the tree-growth response to variability, change, and extremes in climate throughout the Great Lakes region, where the biophysical and socioeconomic impacts of climate change are multifaceted issues of increasing urgency.

Keywords: daily observations, dendroclimatology, warm season hydroclimate, red pine, bimodal precipitation, latewood width, Itasca State Park

\section{INTRODUCTION}

Climate change in the Great Lakes region is clearly identifiable in observational data and model projections (Hayhoe et al., 2010; Andresen et al., 2012; Cook et al., 2020). These general trends toward warmer and wetter conditions give urgency to refining understanding about how climatic change in the coming decades will alter agricultural systems, ecological communities, culture, and society in the Great Lakes region (Kling et al., 2003; Frelich et al., 2021). Tree rings can offer critical long-term context for climate changes in the Great Lakes region. Moisture-sensitive tree-ring chronologies have been used to investigate growth sensitivity to climate conditions 
(Graumlich, 1993; Kipfmueller et al., 2010), and to evaluate century- to millennial-scale variability in warm season drought and precipitation (Blasing and Duvick, 1984; Meko et al., 1993; St. George et al., 2009; Cook et al., 2010; Maxwell J.T. et al., 2020; Stahle et al., 2020; Larson et al., 2021a).

A possible weakening of the statistical relationship between tree rings and warm-season drought has been detected in recent decades in the Great Lakes region (Maxwell et al., 2016; Maxwell J.T. et al., 2020; Heilman et al., 2021). This "Fading Drought Signal" has been attributed to a lack of recent droughts in the region that could reduce radial growth (Maxwell et al., 2016), as well as higher $\mathrm{CO}_{2}$ and plant intrinsic Water Use Efficiency (Heilman et al., 2021). If further replicated across space and tree species, a fading drought signal result would underscore the need to better understand the coupled systems linking climate, environment, and tree growth to ensure robust interpretation of tree rings as a proxy record of Great Lakes hydroclimate. Diagnosing temporal changes in tree growthclimate relationships would be particularly important if the ongoing period of wetness, identified in both observational and paleoclimatic records, persists (Andresen et al., 2012; Ford, 2014; Stahle et al., 2020). Most studies investigating tree growth-climate relationships in the Great Lakes region have used monthlyaggregated climate data and total ring-width. It is unknown if the mechanisms underlying the fading drought signal may be better understood by evaluating climate and growth relationships at multiple timescales, including those that operate at the daily to biweekly timescales which can be obfuscated by time and space aggregation to monthly, seasonal, and regional scales.

A subtle but intriguing feature of precipitation seasonality in the Upper Midwest that could influence tree growth is the presence of two wet peaks during the warm season (Trewartha, 1981; Harrington and Brown, 1985; Keables, 1989). Trewartha (1981) identified two peaks of rainfall (commonly June and September) and described spatiotemporal variability in this bimodal behavior, which fluctuated by decade and between stations. The bimodal precipitation profile can be viewed as a decrease in midsummer precipitation that climatologically follows the primary peak in June and precedes a secondary peak later in the warm season. This precipitation minima has been linked to an increased frequency of circulation patterns in midsummer that favor northerly flow and the advection of cooler, continental air to the Upper Midwest (Keables, 1989). It is reasonable to expect that this subseasonal precipitation variability could influence soil moisture availability and forest stress during the summer growing season. However, to our knowledge, the regional bimodal profile has not been systematically studied in relation to tree growth or tree-ring data. This is despite evidence elsewhere in North America that tree rings can respond to subseasonal precipitation climatologies and anomalies (Edmondson, 2010). A classic example of treegrowth response to a secondary peak in precipitation is the North American summer monsoon in the southwestern United States, which has been reconstructed using networks of latewood treering chronologies (Griffin et al., 2013 and references therein), and more recently investigated used daily climate data and adjusted latewood chronologies (Howard et al., 2021).
Advancing methods in dendroclimatology provide new opportunities to investigate tree growth response to subseasonal climate variability and change. For example, day-wise aggregated climate data is increasingly used to compare with tree-ring proxies instead of the traditional month-wise approach (Vaganov et al., 1999; Ackerman et al., 2017; Jevšenak and Levanič, 2018; Howard and Stahle, 2020; Maxwell R.S. et al., 2020). A principal advantage of this method is that the day-wise approach can highlight tree-growth response to hydroclimate regimes with variability and dynamics that do not conform to Julian calendar months (Howard et al., 2021). Additionally, daily data can be used to characterize changes in the optimal window of tree growth response during the growing season (Jevšenak, 2019). Ideally, the daily data observations would be located in close proximity to the site from which tree-ring data were developed.

The use of sub-annual growth chronologies is another increasingly common method in dendroclimatology. Annual growth rings can be partitioned into sub-annual growth increments (i.e., earlywood and latewood) that can contain stronger and season-specific climate signals (Watson and Luckman, 2016; Stahle et al., 2020). Sub-annual chronologies have been developed across North America (Torbenson et al., 2016), but a gap in publicly-available data exists both in the Great Lakes region, and for red pine (Pinus resinosa), a long-lived and climatically sensitive tree species (Kipfmueller et al., 2010). Across North America, species from the Pinus subgenus have been somewhat unique in terms of their response to late growing season precipitation (Stahle et al., 2020), and the prospects for using red pine in the Great Lakes region are substantial.

Kipfmueller et al. (in press) developed new sub-annual red pine chronologies near Lake Itasca, the headwaters of the Mississippi River, in Itasca State Park (ISP), Minnesota. In comparison to earlywood-width and total ring-width, the latewood-width timeseries from ISP exhibited stronger internal crossdating in ring-width patterns and statistical covariance within and between trees. Kipfmueller et al. (in press) found the strongest relationships between warm-season precipitation and summer forming latewood-width. However, analyses of daily-scale observations and temporal stability of the climatetree growth relationships were not conducted in that study. Subsequently, exploratory analysis of the correlation between their latewood data and divisional PDSI data (Vose et al., 2014) indicated: (1) a notable decline in PDSI-latewood covariance during recent decades (not shown), and (2) the dominant role of precipitation as a historical driver of PDSI variability, consistent with the results of St. George et al. (2010). Exploratory analysis also indicated a decrease in midsummer rainfall in the daily precipitation climatology, raising the question as to whether red pine growth at ISP is sensitive to this subseasonal precipitation variability over time.

This pilot study offers a close examination of changes and trends in the daily observational climate record at ISP, and a diagnosis of the strength and temporal stability of the tree-growth response to climate across daily to multidecadal timescales. Specific objectives of this study are to (1) assess trends in the observational climate record at ISP, (2) investigate the climatic drivers of sub-annual growth chronologies at ISP using daily 
climate data, and (3) examine the temporal stability of the daily precipitation response of latewood width at ISP using multiple methods.

\section{DATA}

We collected increment cores from living red pine trees in Itasca State Park, located in north central Minnesota. Each series was surfaced using a core microtome, visually crossdated (Stokes and Smiley, 1996), and earlywood-, latewood-, and total ring widths were measured to the nearest $0.001 \mathrm{~mm}$. Ring-width measurements were detrended using a 150-year cubic spline and the 131 individual series were combined into a single chronology using Tukey's bi-weight robust mean (Kipfmueller et al., in press). Daily precipitation and temperature data were acquired from the University of Minnesota Itasca Biological Station and Laboratories weather station located in ISP (Figures 1D,E; GHCND ID: USC00214106). We focused our analyses on unadjusted latewood and precipitation and minimum temperature, which were found to be the strongest tree-ring climate covariates by Kipfmueller et al. (in press). The ISP station, located $<10$ kilometers from the trees we sampled, has a daily record that extends from 1911 to present with $<2 \%$ missing values.

\section{METHODS}

We used a multiple linear regression approach to estimate missing daily data from the ISP station. Daily precipitation and minimum temperature data were acquired from three Historical Climatology Network stations surrounding ISP (Menne et al., 2012). Multiple linear regression was used with the ISP record as the predictand and the other three stations as predictors to estimate missing precipitation and minimum temperature values for the full 1912-2020 period. We used quantile mapping to adjust the distribution of the filled-in precipitation values toward the distribution of the observed ISP precipitation data, in an attempt to mitigate errors common to regression-based imputation methods, i.e., the overestimation of the number of wet days and underestimation of the number of heavy precipitation events (Simolo et al., 2010; Gudmundsson et al., 2012). Trends in precipitation and temperature from 1912 to 2020 were assessed using linear regression. We calculated the length of the freeze-free season using the traditional definition based on the number of days between the last spring freeze and first autumn freeze $\left(\mathrm{T}_{\min }<0^{\circ} \mathrm{C}\right)$. Differences in mean daily precipitation were identified using the non-parametric KruskalWallis test and a post-hoc Dunn's test with $p$-values adjusted using the Holm method.

We assessed tree growth response to daily climate data using the daily_response() function in the $\mathrm{R}$ package dendroTools which compares tree-ring parameters and a daily climate variable using a moving window of variable widths (Jevšenak and Levanič, 2018). Earlywood-, latewood-, and total-ring width were correlated with daily total precipitation and mean minimum temperature aggregated into all windows between 10 and 365 days. Windows of daily-aggregated climate data advance in 1day increments starting with day of year (DOY) 1 and finishing with DOY 365. Pearson correlation coefficients were calculated using a window of 24 months from January in the previous year to December in the current year for the years 19132018. The large number of correlation tests carried out by the daily_response() function inflates the number of theoretical type I errors (Jevšenak, 2019). To correct for test multiplicity and reduce the risk of identifying spurious correlations as significant, we applied the False Discovery Rate procedure (Benjamini and Hochberg, 1995) with a $q$-value of 0.05 to match our p-value threshold.

We used multiple approaches to assess the time stability of growth-climate relationships. First, we used the daily_response() function to calculate correlations between latewood width and daily climate data for the full common period (1913-2018). Second, we repeated use of this approach for three nonoverlapping subperiods of approximately equal length (early, 1913-1947; middle, 1948-1983; late, 1984-2018). As described fully below, the strongest latewood correlations in the full period analysis were for a 12-day critical climate period in late July and early August (July 27-August 7; hereafter "12day CCP") and a 109-day critical climate period from late May through early September (May 25-September 10; hereafter "seasonal CCP"). Third, to investigate the time stability of latewood response to the 12-day and seasonal CCPs, we extracted daily-aggregated precipitation each year corresponding to the July 27-August 7 and the May 25-September 10 periods, resulting in two precipitation time series for the full period from 1913-2018. Fourth, we used a 31-year running correlation to compare each precipitation time series with the latewood chronology from 1913 to 2018. The power of running correlation analysis is hampered by the reduced degrees of freedom, particularly when using climatic timeseries that exhibit routinely characteristic autocorrelation (Hu et al., 2017). Consequently, we also investigated possible time-dependence in growth-climate relationships using a Bayesian generalized linear model as a dynamic regression modeling procedure (Helske, 2021). Like the application of the Kalman filter method in dendroclimatology (Visser and Molenaar, 1988; Cook et al., 2002), this method allows regression coefficients to vary as a random walk and uses the Kalman filter to objectively identify time-dependence in the relationship between predictor and predictand variables. However, this Bayesian method uses Markov chain Monte Carlo sampling of the posterior distribution to estimate the unknown regression coefficients rather than maximum likelihood estimation. All analysis presented here was conducted in the statistical software $\mathrm{R}$ [version 4.0.3; R Core Team, 2020].

\section{RESULTS}

May-October is the season that may be most relevant to red pine radial growth (Kipfmueller et al., in press), and the ISP station showed an increasing linear trend in warm season (May-October) precipitation $\left(11.6 \mathrm{~mm} \mathrm{decade}{ }^{-1}\right.$; Figure 1B). 
A

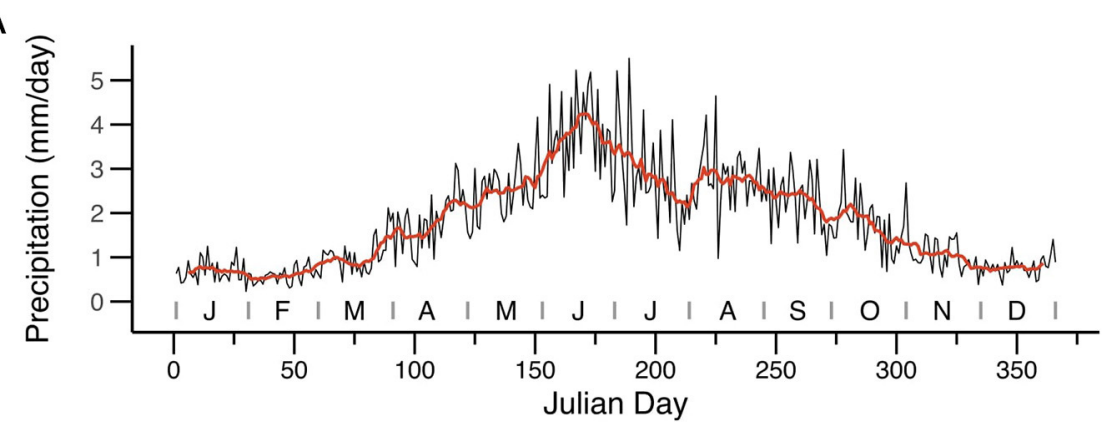

B
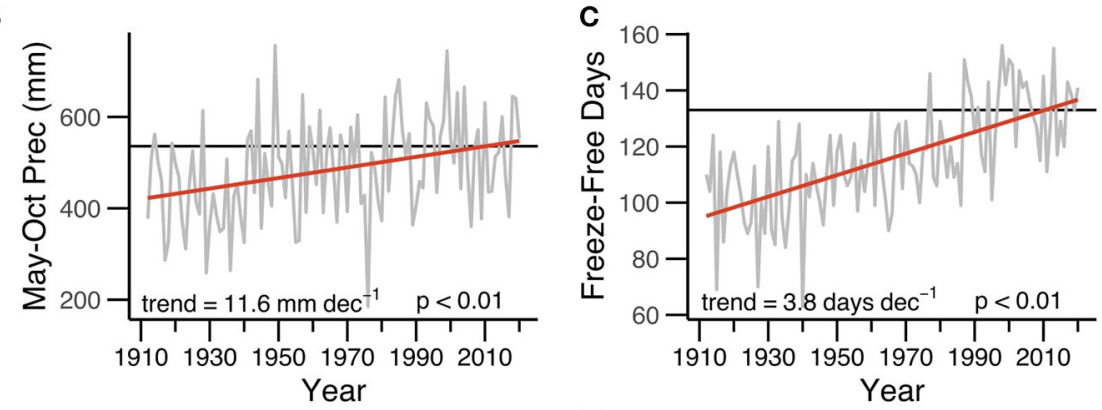

D

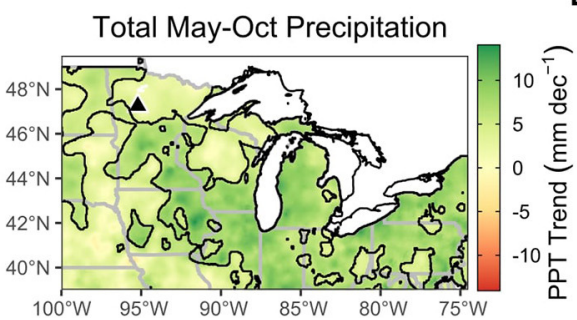

E

Mean May-Oct Minimum Temp

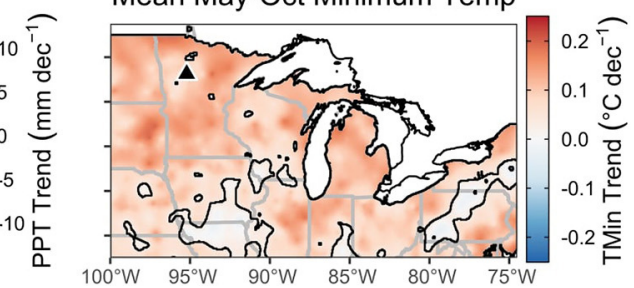

FIGURE 1 | Characteristics of climatology and change at Itasca State Park. Mean daily precipitation (black line) and 11-day moving average precipitation (red line) for the period 1912-2020 (A). Timeseries (gray) and linear trend (red), and 1991-2020 mean (black) for warm-season (May-October) precipitation and freeze-free season length (days; $0^{\circ} \mathrm{C}$ minimum temperature threshold) for 1912-2020 (B,C). Regional-scale linear trends in CLIMGRID warm season (May-October) precipitation (D) and minimum temperature (E) for 1895-2020, with the black contour encompassing areas where trend test $p$-values were $<0.05$.

Although increasing trends in precipitation were found in every season and in every month except for January at ISP, the strongest increases were found in September, October, and the SON season (Supplementary Figure 1). Warming trends at ISP were reflected in a substantially longer freeze-free season (3.8 days decade ${ }^{-1}$; Figure 1C). Additionally, large increases in minimum temperature were found in every season and month except February, April, October, and November (Supplementary Figure 2). These increases in precipitation and minimum temperature from the ISP station are consistent with the broad scale spatial pattern of trends toward warmer and wetter warm-season conditions in the Great Lakes region (Figures 1D,E).

Sub-annual tree-ring chronologies from ISP exhibited correlation coefficients with daily precipitation and minimum temperature with magnitudes that can be considered strong for red pine in this region (i.e., $r>0.45$ ) over intervals ranging from 10 to 365 days, but in general the strongest relationships were between warm-season precipitation and latewood (Figures 2A-C; Supplementary Figure 3). Over the full period from 1913 to 2018, the daily precipitation window that had the highest correlation with latewood width was from Julian Day 145-253, or May 25 to September $10(r=$ 0.508; Supplementary Figure 3; seasonal CCP). In addition to long seasonal windows of response, strong to moderate correlations between warm-season precipitation and latewood were also observed for shorter time windows (e.g., 10-20 days; Figures 2A,B). Over the full period, the short daily precipitation window that had the highest correlation with latewood width was from Julian Days 208-219, or July 27 to August 7 ( $r=0.383$; Supplementary Figure 3; 12-day CCP). Growth-climate results were similar using daily climate data containing imputed or missing values.

Daily analysis for non-overlapping periods revealed a strong to moderate summer precipitation signal in red pine latewood with a growth response that was similar in magnitude and timing in the early and middle periods (Figures 2A,B). However, the magnitude and frequency of positive correlations diminished in the most recent late period (Figure $2 \mathrm{C}$ ). The optimal windows of warm-season precipitation response in latewood, as calculated 


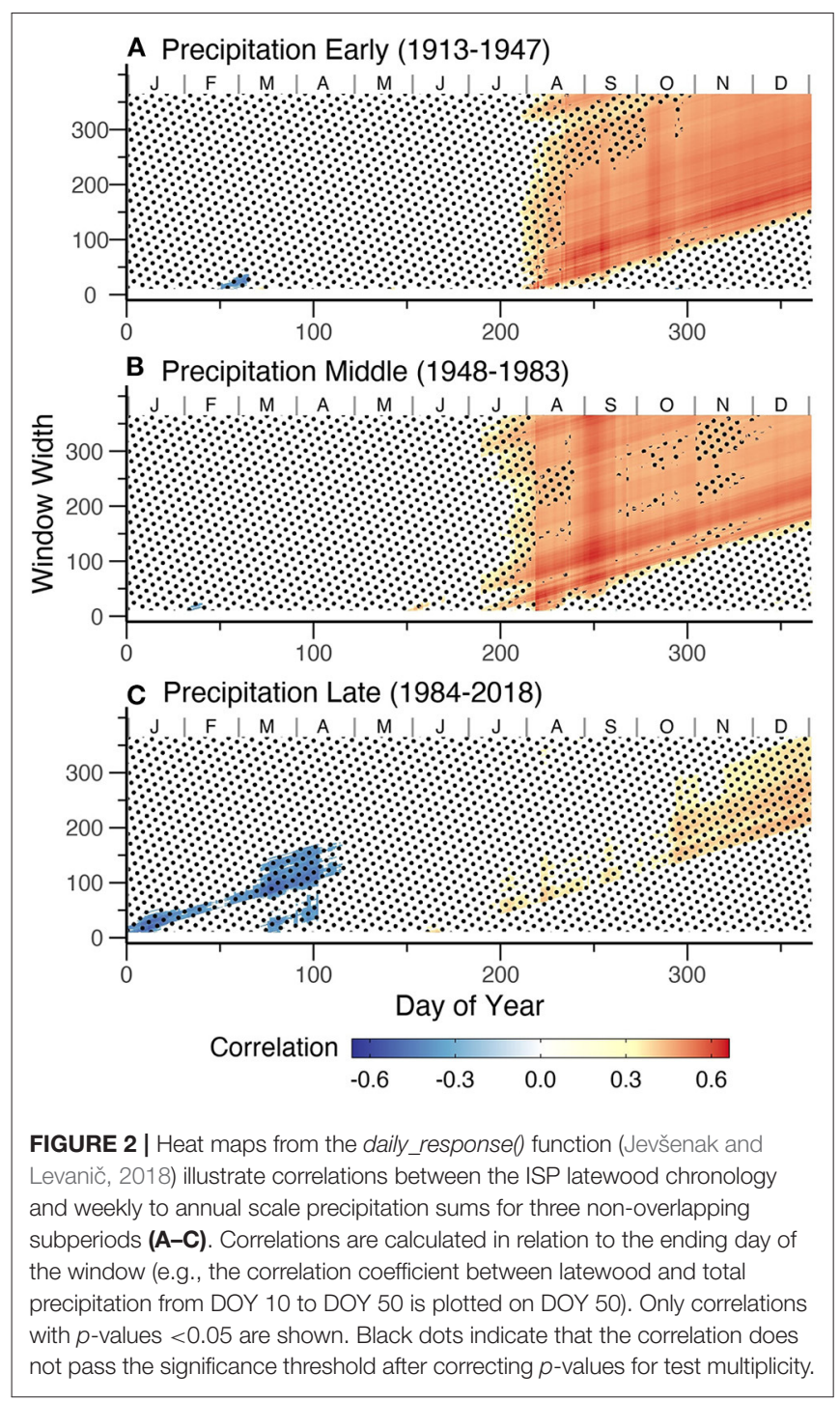

using the daily_response() function, differed between the early ( $r$ $=0.651$; June 21 to September 10$)$, middle $(r=0.658$; July 27 to August 6 ), and late ( $r=0.458$; June 6 to June 15) periods.

The daily precipitation climatology in split periods showed increasing annual precipitation over time at ISP (Figure 3A). Running correlations using a fixed 12-day window revealed correlations between latewood and precipitation that peaked on the 12-day CCP straddling July and August (Figure 3B). This 12day response over late July to early August was moderate for the full period ( $r=0.383$; July 27 to August 7), although split-period analysis revealed that this response was temporally unstable (Figures 3B, 4A). Twelve-day correlations in midsummer were considerably stronger in the early $(r=0.583$; July 25 to August $5)$ and middle ( $r=0.608$; July 27 to August 7$)$ periods, and close to zero in the late period. Notably, this 2-week interval in midsummer coincides with a local minima in the daily precipitation climatology at ISP that is evident in the full period (Figure 1A). While this minima in the precipitation climatology

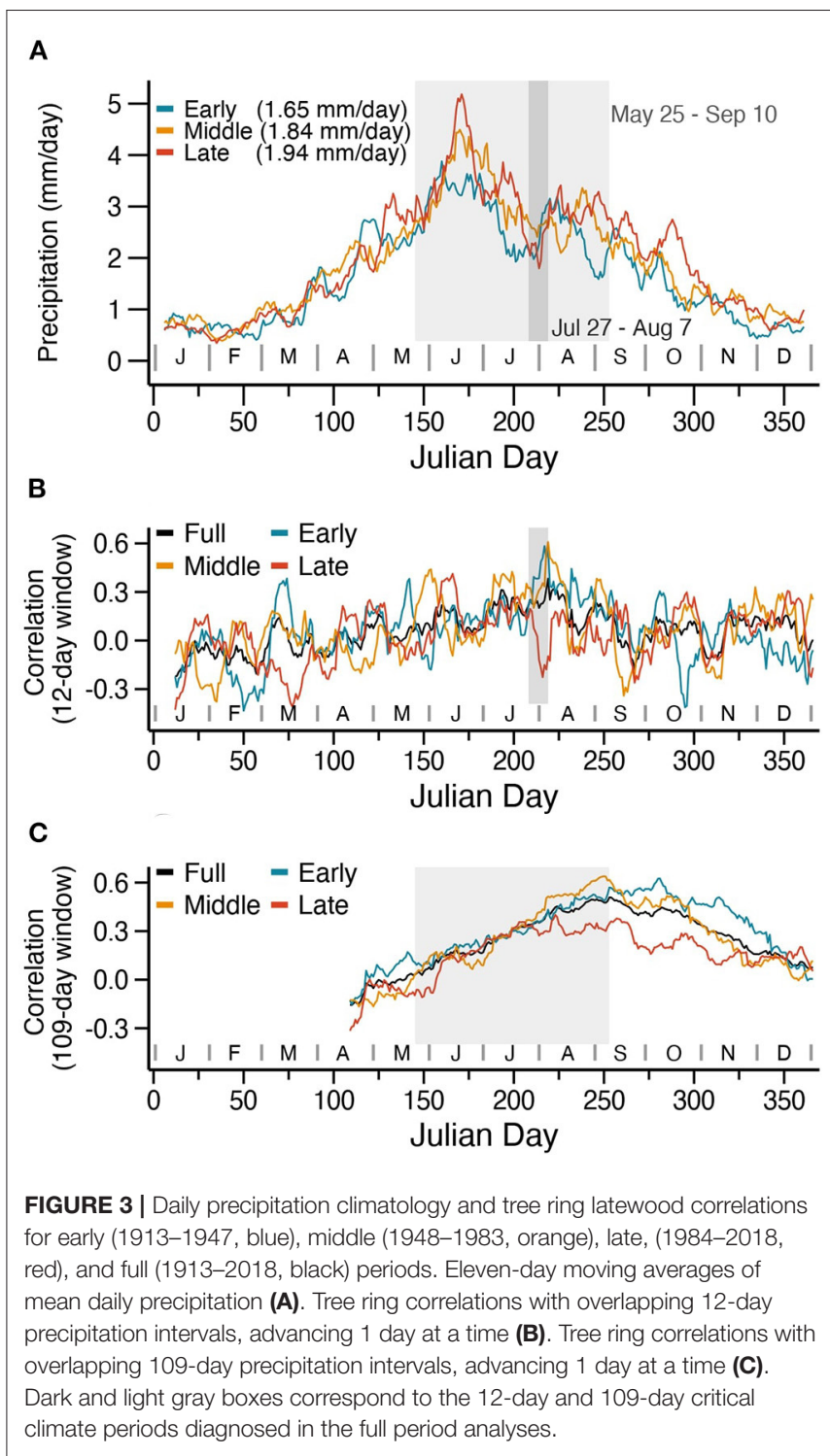

also appears relatively stable in the split periods (Figure 3A), mean precipitation for the 2 -week period immediately preceding the minima (July 12-27) has increased from the early to late period (Kruskal-Wallis test statistic $=2.84 ; p=0.014$ ). The deteriorating tree-ring response to midsummer conditions is further illustrated with a time series comparison of latewood and total precipitation for the 12-day CCP (Figure 4B). Dynamic regression analysis between latewood and the 12-day CCP shows a relationship that was positive and strong throughout the earlyto mid-20th century before weakening markedly to zero after the 1970s (Figure 4C).

Running correlations using a fixed 109-day window revealed correlations between latewood and total precipitation that were strong to moderate in all three periods (Figures 3C, 4D). The seasonal scale response was strongest in the early $(r=0.626$; June 22 to October 8$)$ and middle ( $r=0.639$; May 22 to September 7$)$ 

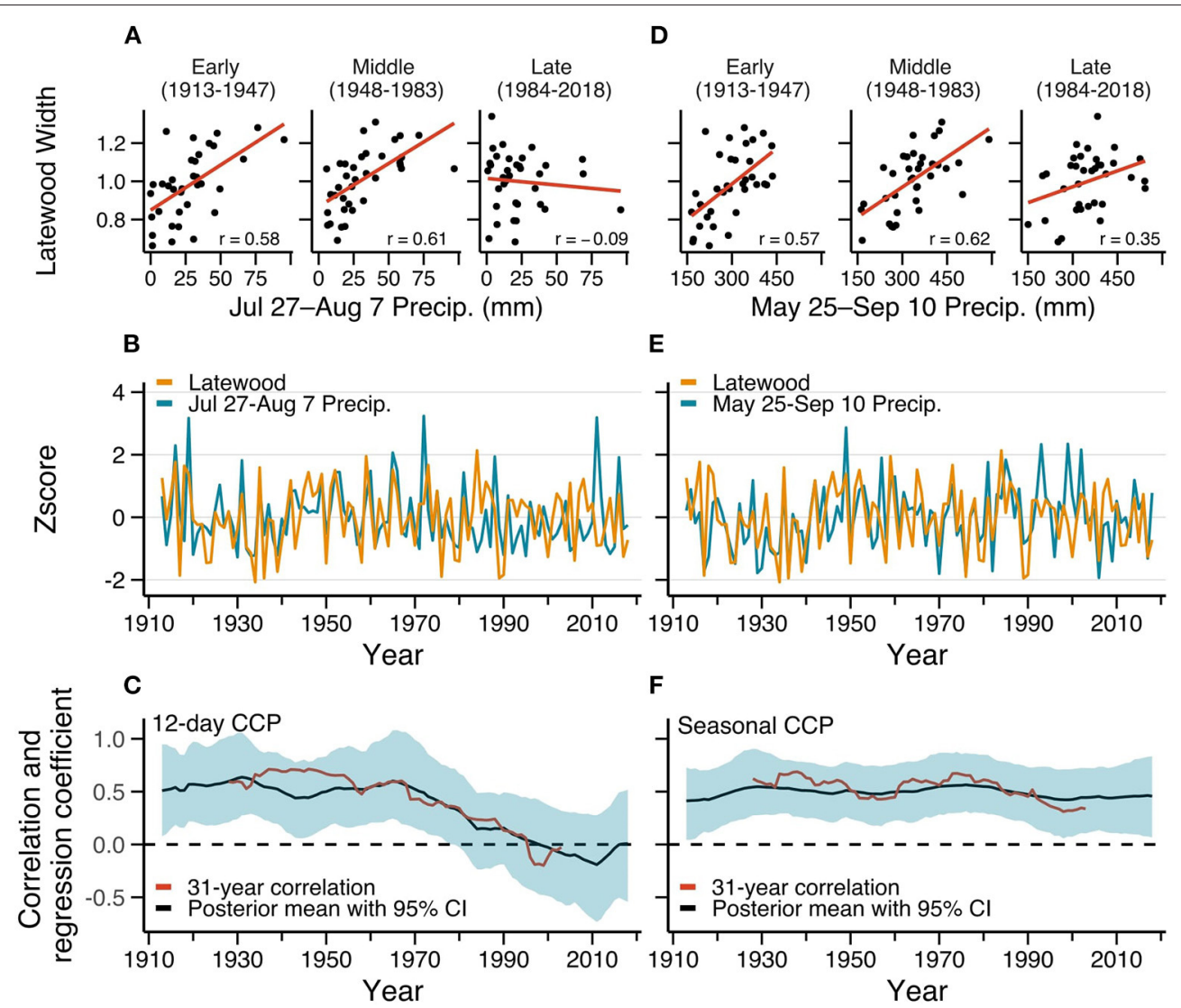

FIGURE 4 | Tree ring latewood vs. daily precipitation for the July 27-August 7 subseasonal (A-C) and the May 25-September 10 seasonal (D-F) windows determined to exhibit maximum covariance. Scatter plots illustrate the linearity of relationships for three non-overlapping periods spanning the full common period (A,D). Timeseries plots illustrate z-scores for the data standardized over the 1912-2018 common period (B,E). The bottom row (C,F) illustrates running 31-year correlations (red lines) and Bayesian generalized linear models of time varying coefficients (solid black lines). Blue shaded areas represent uncertainty estimated with $95 \%$ credible intervals for the regression coefficients.

periods before weakening in the late $(r=0.4$; April 25 to August 11) period. The differences between latewood-precipitation correlations in the three non-overlapping periods were not statistically clear (all $p>0.05$ ). A time series comparison shows additional evidence for time-dependence in the relationship between latewood width and total precipitation for the seasonal CCP (Figure 4E). Dynamic regression analysis showed a positive relationship between latewood and the seasonal CCP that varied throughout the early- to mid-20th century before weakening after about 1980 (Figure 4F). The 95\% credible intervals of the time-varying regression coefficients do not contain zero throughout the full period of 1913-2018 (Figure 4C), suggesting a response that has diminished in the past several decades but remains moderate.

\section{DISCUSSION}

A short term, midsummer window of precipitation variability seems to have been a major control on red pine tree growth and latewood width at ISP from the 1910s through the early 1980s. This 12-day CCP was found to be embedded within the broader, multi-month seasonal response to warm-season precipitation at
ISP. Results from several statistical approaches robustly indicate that the strength of these subseasonal and seasonal precipitation signals has diminished in recent decades. Precipitation in the 12day CCP has not been strongly correlated with latewood width since the 1980s. The seasonal CCP correlation also weakened appreciably in recent decades, though hydroclimatic variability during this multi-month period must still be important for tree growth. The late May through early September season does correspond to the historical timing of cambial activity for red pine, as detected through observations in north-eastern Minnesota (Ahlgren, 1957). Nevertheless, it is abundantly clear that the strength of the precipitation signal in red pine at ISP has faded over recent decades.

As scientists increasingly recognize the prevalence of nonstationary relationships between tree growth and climate (e.g., D'Arrigo et al., 2008), there has been a growing effort to critically examine the stability of climate-growth relationships over the full instrumental climate record (Wilmking et al., 2020). Some studies in the Great Lakes region demonstrate a decrease in sensitivity of radial tree growth to precipitation and drought (Maxwell et al., 2016; Heilman et al., 2021). Our results, although limited to a single site, are consistent with these studies and show what is, 
to our knowledge, the first evidence for declining precipitation sensitivity in red pine.

Daily climate data analysis facilitated improved understanding of short-term (days to weeks) changes in the hydroclimatology at ISP that could not be easily detected at coarser temporal scales but may contribute to the weakening latewood-precipitation relationship. Specifically, the response of latewood to warm-season precipitation at ISP remains moderate for the seasonal CCP but the 12-day CCP response is absent in recent decades (Figures 2, 4C). The declining precipitation sensitivity in red pine latewood co-occurs with climatic changes at ISP that could hypothetically alter the conditions limiting to radial tree growth, including increases in precipitation (Supplementary Figure 1) and minimum temperature (Supplementary Figure 2), and a lengthening freeze-free season (Figure 1C). In addition, increases in atmospheric $\mathrm{CO}_{2}$ (Heilman et al., 2021), and the local disturbance history at ISP could contribute to the fading strength of the rainfall signal in red pine at this site. Known disturbances at ISP include reduced fire activity and possible changes in understory composition and density since the park's establishment in 1891 (Frissell, 1973), wind events (Webb et al., 2001), and changes in nutrient status (Howard and McLauchlan, 2015).

The once important 12-day CCP from late July to early August has coincided with a relative minima in the climatological mean of midsummer rainfall at ISP. While this midsummer break in mean-state precipitation has remained relatively stable over time at ISP, the magnitude and timing of climatological rainfall bursts in the weeks before and after this dry period have been variable at ISP (Figure 3A), and elsewhere in the Midwest (Trewartha, 1981). It could be relevant that the 2 weeks leading up to the 12-day CCP were wetter in the late (19842018) period (Figure 3A). This is a key multi-week season in midsummer when temperature and evaporative demand remain near their annual maximum. Might wetter conditions leading into the start of the 12-day CCP impart enough moisture to buffer trees against enhanced moisture stress during the relatively dry 12-day CCP? Though beyond the brief scope of this pilot study, systematic attribution research is needed to diagnose the interplay of the coupled and non-stationary systems linking climate, environment, and tree growth at ISP. This might be accomplished with analysis of additional datasets from elsewhere in the region, and with careful modeling of water balance across multiple timescales and time periods. Forward models that simulate tree-ring formation using daily climate data constitute another powerful tool to understand temporal shifts in growthlimiting factors (Anchukaitis et al., 2006, 2020; Bunn et al., 2018; Jevšenak et al., 2021) and this approach could provide a complementary perspective of relevance to the use of red pine for making paleoclimate inference.

Using daily precipitation data, we observed many growthclimate correlations with higher magnitudes than those observed in other red pine studies using monthly data (e.g., Kipfmueller et al., 2010; D'Amato et al., 2013). However, there are limitations to this approach. While the day-wise method is flexible in that it ignores calendar month boundaries, the substantial number of correlations calculated greatly inflates the number of theoretical type I errors (Jevšenak, 2019). For precipitation data in particular, short-term (days to weeks) totals are frequently noisy and heavily skewed, which could lead to spurious correlations with tree-ring data. It is thus important to ensure that daily windows with correlation magnitudes deemed meaningful fit with site-specific understanding of the environmental processes leading to ring width formation. In this study, we focused covariance analysis on the precipitation and minimum temperature variables, which Kipfmueller et al. (in press) detected to be potentially relevant controls on tree growth. Although our results show relatively weak correlations between latewood and minimum temperature data, the increases in minimum temperature and lengthening freeze-free season evident at ISP, and indeed across much of the Great Lakes region (e.g., Skaggs and Baker, 1985; Robeson, 2002), have significant practical implications for plant communities including red pine. For example, a lengthened growing season could have a strong influence on red pine phenology and the timing of growth responses to temperature in the transition spring and fall seasons. The application of multiple tree-ring proxies, ranging from quantitative wood anatomy (Arnič et al., 2021) to stable isotopes (Maxwell R.S. et al., 2020), as well as cambial phenology (Moser et al., 2010), constitute a promising way forward to improve process-level understanding of the dailyscale drivers of wood formation at this site.

Many forest systems are experiencing alarming signs of decline (Allen et al., 2010, 2015). Climate change in the Great Lakes region holds unknown consequences for the future health of red pine. Here we identify a diminishing moisture signal that may continue to decay with projected changes in the amount and timing of precipitation. Moreover, frequent fire in red pine ecosystems results in a xerification of the landscape that benefits red pine regeneration and persistence (Larson et al., 2021b). Projected increases in precipitation, coupled with the ongoing removal of fire from Great Lake forests, may jeopardize the overall health of red pine. Nearly a century of fire suppression in remnant red pine forests of the Great Lakes region may have also led to dramatic changes in forest composition, structure, and competitive effects. These factors have been shown to alter red pine radial growth and climate sensitivity (Aakala et al., 2013; D'Amato et al., 2013; Magruder et al., 2013), highlighting the uncertainty of red pine growth response to climate change.

\section{CONCLUSION}

This pilot study provides a new perspective on the timescales of climatic response of red pine, an important tree species for reconstructions of drought and seasonal precipitation in the upper Great Lakes region. In addition to long seasonal windows, the daily data covariance approach identified a critical climate period for tree growth that coincided with a distinct but perhaps understudied feature of the regional precipitation climatology. If replicated across additional locations and tree species, the short-term response shown here could indicate an important coupling between tree growth in the late growing season and the bimodal warm-season precipitation profile previously identified in the Upper Midwest. We believe there is potential to diagnose critical climate periods for tree growth using daily data elsewhere in the Great Lakes region. Further, close 
evaluation of the daily climate record over time at sites with colocated tree-ring and observational data may highlight possible mechanisms driving the fading drought signal in regional treering chronologies. The statistical growth-climate relationships presented here do not imply causal links and developing better process-based understanding of the multivariate climate response of red pine remains a priority. Nonetheless, the results presented here suggest that the daily-scale approach can be a valuable complement to typical dendroclimatic studies that use monthly data.

\section{DATA AVAILABILITY STATEMENT}

The tree-ring data for this study will be found in the International Tree-Ring Data Bank (ITRDB) upon publication: https:// www.ncei.noaa.gov/products/paleoclimatology/tree-ring.

The University of Minnesota Itasca Biological Station and Laboratories weather station data is available from the National Oceanic and Atmospheric Administration: https://www. ncdc.noaa.gov/cdo-web/datasets/GHCND/stations/GHCND:

USC00214106/detail.

\section{AUTHOR CONTRIBUTIONS}

KK secured funding and sampling permission for field collection of tree ring data. MT and DG designed the methods. MT performed analyses and prepared figures with oversight and feedback from DG, EM, and KK. MT wrote the first draft of the paper and managed writing contributions from DG, EM, and KK. All authors participated in fieldwork and tree-ring chronology development and contributed to the interpretation of the data.

\section{REFERENCES}

Aakala, T., Fraver, S., D'Amato, A. W., and Palik, B. J. (2013). Influence of competition and age on tree growth in structurally complex old-growth forests in northern Minnesota, USA. For. Ecol. Manage. 308, 128-135. doi: 10.1016/j.foreco.2013.07.057

Ackerman, D., Griffin, D., Hobbie, S. E., and Finlay, J. C. (2017). Arctic shrub growth trajectories differ across soil moisture levels. Glob. Chang. Biol. 23, 4294-4302. doi: 10.1111/gcb.13677

Ahlgren, C. E. (1957). Phenological observations of nineteen native tree species in Northeastern Minnesota. Ecology 38, 622-628. doi: 10.2307/1943128

Allen, C. D., Breshears, D. D., and McDowell, N. G. (2015). On underestimation of global vulnerability to tree mortality and forest die-off from hotter drought in the Anthropocene. Ecosphere 6, 1-55. doi: 10.1890/ES15-00203.1

Allen, C. D., Macalady, A. K., Chenchouni, H., Bachelet, D., McDowell, N., Vennetier, M., et al. (2010). A global overview of drought and heat-induced tree mortality reveals emerging climate change risks for forests. For. Ecol. Manage. 259, 660-684. doi: 10.1016/j.foreco.2009.09.001

Anchukaitis, K. J., Evans, M. N., Hughes, M. K., and Vaganov, E. A. (2020). An interpreted language implementation of the VaganovShashkin tree-ring proxy system model. Dendrochronologia 60:125677. doi: 10.1016/j.dendro.2020.125677

Anchukaitis, K. J., Evans, M. N., Kaplan, A., Vaganov, E. A., Hughes, M. K., Grissino-Mayer, H. D., et al. (2006). Forward modeling of regional scale treering patterns in the southeastern United States and the recent influence of summer drought. Geophys. Res. Lett. 33:L04705. doi: 10.1029/2005GL025050

\section{FUNDING}

This work was not funded by a grant or other funding sources. We declare no specific funding for this work.

\section{ACKNOWLEDGMENTS}

The lands currently defined as Itasca State Park were frequently used by the Dakota and more recently the Ojibwe, besides its use by earlier cultural groups, prior to European colonization. We acknowledge and are grateful for the opportunity to gather and deploy tree-ring resources from this land to inform our research and findings. We thank the personnel from the Minnesota Department of Natural Resources for granting us sampling permission in Itasca State Park. We also thank the personnel at the University of Minnesota Itasca Biological Station and Laboratories, especially Jonathan Schilling, Lesley Knoll, and Laura Domine, for logistical support and helpful discussions about research in the park. Daniel Brumm, Daniel Crawford, Jared Stachiw, Evan Larson, Lane Johnson, Elizabeth Schneider, and undergraduate students from the University of WisconsinPlatteville provided critical assistance in the field and laboratory work. We thank the personnel from the Chippewa National Forest and students and staff from the Leech Lake Tribal College STEM Club for their fieldwork assistance and insightful comments and perspectives.

\section{SUPPLEMENTARY MATERIAL}

The Supplementary Material for this article can be found online at: https://www.frontiersin.org/articles/10.3389/frwa. 2021.801265/full\#supplementary-material

Andresen, J., Hilberg, S., Kunkel, K., and Center, M. R. C. (2012). "Historical climate and climate trends in the midwestern USA," in U.S. National Climate Assessment Midwest Technical Input Report, eds J. Winkler, J. Andresen, J. Hatfield, D. Bidwell, D. Brown, et al. [The Great Lakes Integrated Sciences and Assessments (GLISA) Center]. Available from: http://glisa.msu.edu/docs/NCA/ MTIT_Historical.pdf (accessed September 20, 2021).

Arnič, D., Gričar, J., Jevšenak, J., BoŽič, G., von Arx, G., and Prislan, P. (2021). Different wood anatomical and growth responses in European Beech (Fagus sylvatica L.) at three forest sites in Slovenia. Front. Plant Sci. 1551. 12. doi: $10.3389 /$ fpls.2021.669229

Benjamini, Y., and Hochberg, Y. (1995). Controlling the false discovery rate: a practical and powerful approach to multiple testing. J. R. Stat. Soc. Ser. B 57, 289-300. doi: 10.1111/j.2517-6161.1995.tb02031.x

Blasing, T. J., and Duvick, D. (1984). Reconstruction of precipitation history in North American corn belt using tree rings. Nature 307, 143-145. doi: $10.1038 / 307143 \mathrm{a} 0$

Bunn, A. G., Salzer, M. W., Anchukaitis, K. J., Bruening, J. M., and Hughes, M. K. (2018). Spatiotemporal variability in the climate growth response of high elevation Bristlecone Pine in the White Mountains of California. Geophys. Res. Lett. 45, 13312-13321. doi: 10.1029/2018GL080981

Cook, B. I., Mankin, J. S., Marvel, K., Williams, A. P., Smerdon, J. E., and Anchukaitis, K. J. (2020). Twenty-first century drought projections in the CMIP6 forcing scenarios. Earths Fut. 8:e2019EF001461. doi: 10.1029/2019EF001461

Cook, E. R., D’Arrigo, R. D., and Mann, M. E. (2002). A wellverified, multiproxy reconstruction of the winter North Atlantic 
Oscillation index since A.D. 1400. J. Clim. 15, 1754-1764. doi: 10.1175/1520-0442(2002)015<1754:AWVMRO > 2.0.CO;2

Cook, E. R., Seager, R., Heim, R. R., Vose, R. S., Herweijer, C., and Woodhouse, C. (2010). Megadroughts in North America: placing IPCC projections of hydroclimatic change in a long-term palaeoclimate context. J. Quat. Sci. 25, 48-61. doi: 10.1002 /jqs.1303

D'Amato, A. W., Bradford, J. B., Fraver, S., and Palik, B. J. (2013). Effects of thinning on drought vulnerability and climate response in north temperate forest ecosystems. Ecol. Appl. 23, 1735-1742. doi: 10.1890/13-0677.1

D'Arrigo, R., Wilson, R., Liepert, B., and Cherubini, P. (2008). On the 'Divergence Problem' in Northern Forests: a review of the tree-ring evidence and possible causes. Global Planet. Change 60, 289-305. doi: 10.1016/j.gloplacha.2007.03.004

Edmondson, J. R. (2010). The meteorological significance of false rings in eastern redcedar (Juniperus virginiana L.) from the Southern Great Plains, U.S.A. Tree Ring Res. 66, 19-33. doi: 10.3959/2008-13.1

Ford, T. W. (2014). Precipitation anomalies in Eastern-Central Iowa from 1640 Present. J. Hydrol. 519, 918-924. doi: 10.1016/j.jhydrol.2014.08.021

Frelich, L. E., Montgomery, R. A., and Reich, P. B. (2021). Seven ways a warming climate can kill the Southern Boreal Forest. Forests. 12:560. doi: $10.3390 / f 12050560$

Frissell, S. S. (1973). The importance of fire as a natural ecological factor in Itasca State Park, Minnesota. Quat. Res. 3, 397-407. doi: 10.1016/0033-5894(73)90005-7

Graumlich, L. J. (1993). Response of tree growth to climatic variation in the mixed conifer and deciduous forests of the upper Great Lakes region. Can. J. For. Res. 23, 133-143. doi: 10.1139/x93-020

Griffin, D., Woodhouse, C. A., Meko, D. M., Stahle, D. W., Faulstich, H. L., Carrillo, C., et al. (2013). North American monsoon precipitation reconstructed from tree-ring latewood. Geophys. Res. Lett. 40, 954-958. doi: 10.1002/grl.50184

Gudmundsson, L., Bremnes, J. B., Haugen, J. E., and Engen-Skaugen, T. (2012). Technical Note: Downscaling RCM precipitation to the station scale using statistical transformations - A comparison of methods. Hydrology and Earth System Sciences, 16:3383-3390. doi: 10.5194/hess-16-3383-2012

Harrington, J. A., and Brown, B. J. (1985). A synoptic climatology of depressions in warm season precipitation profiles from the upper middle west. Phys. Geogr. 6, 186-197. doi: 10.1080/02723646.1985.10642270

Hayhoe, K., VanDorn, J., Croley, T., Schlegal, N., and Wuebbles, D. (2010). Regional climate change projections for Chicago and the US Great Lakes. J. Great Lakes Res. 36, 7-21. doi: 10.1016/j.jglr.2010.03.012

Heilman, K. A., Trouet, V. M., Belmecheri, S., Pederson, N., Berke, M. A., and McLachlan, J. S. (2021). Increased water use efficiency leads to decreased precipitation sensitivity of tree growth, but is offset by high temperatures. Oecologia 1, 1-16. doi: 10.1007/s00442-021-04892-0

Helske, J. (2021). walker: Bayesian Generalized Linear Models With Time-Varying Coefficients. R package version 1.0.2. Available online at: https:/github.com/ helske/walker (accessed December 3, 2021).

Howard, I., and McLauchlan, K. K. (2015). Spatiotemporal analysis of nitrogen cycling in a mixed coniferous forest of the northern United States. Biogeosciences 12, 3941-3952. doi: 10.5194/bg-12-3941-2015

Howard, I. M., and Stahle, D. W. (2020). Tree-ring reconstruction of single-day precipitation totals over Eastern Colorado. Monthly Weather Rev. 148, 597-612. doi: 10.1175/MWR-D-19-0114.1

Howard, I. M., Stahle, D. W., Torbenson, M. C. A., and Griffin, D. (2021). The summer precipitation response of latewood tree-ring chronologies in the southwestern United States. Int. J. Climatol. 41, 2913-2933. doi: 10.1002/joc.6997

Hu, J., Emile-Geay, J., and Partin, J. (2017). Correlation-based interpretations of paleoclimate data - where statistics meet past climates. Earth Planet. Sci. Lett. 459, 362-371. doi: 10.1016/j.epsl.2016.11.048

Jevšenak, J. (2019). Daily climate data reveal stronger climate-growth relationships for an extended European tree-ring network. Quat. Sci. Rev. 221:105868. doi: $10.1016 /$ j.quascirev.2019.105868

Jevšenak, J., and Levanič, T. (2018). dendroTools: R package for studying linear and nonlinear responses between tree-rings and daily environmental data. Dendrochronologia 48, 32-39. doi: 10.1016/j.dendro.2018. 01.005

Jevšenak, J., Tychkov, I., Gričar, J., Levani,č, T., Tumajer, J., Prislan, P., et al. (2021). Growth-limiting factors and climate response variability in Norway spruce
(Picea abies L.) along an elevation and precipitation gradients in Slovenia. Int. J. Biometeorol. 65, 311-324. doi: 10.1007/s00484-020-02033-5

Keables, M. J. (1989). A synoptic climatology of the bimodal precipitation distribution in the upper midwest. J. Clim. 2, 1289-1294. doi: 10.1175/15200442(1989)002<1289:ASCOTB > 2.0.CO;2

Kipfmueller, K. F., Elliott, G. P., Larson, E. R., and Salzer, M. W. (2010). An assessment of the dendroclimatic potential of three conifer species in Northern Minnesota. Tree Ring Res. 66, 113-126. doi: 10.3959/2009-12.1

Kipfmueller, K. F., Montpellier, E.E., Trumper, M.L., and Griffin, D. (in press). Intra-annual ring width and climate response of red pine in Itasca State Park in north-central Minnesota. Can. J. For. Res.

Kling, G. W., Hayhoe, K., Johnson, L. B., Magnuson, J. J., Polasky, S., Robinson, S. K., et al. (2003). Confronting Climate Change in the Great Lakes Region: Impacts on Our Communities and Ecosystems. Cambridge, MA: Union of Concerned Scientists; Washington, DC: Ecological Society of America.

Larson, E. R., Allen, S. A., and Underwood, C. A. (2021a). The driftless oaks: a new network of tree-ring chronologies to improve regional perspectives of drought in the Upper Midwest, USA. Progr. Phys. Geogr. 45:375-406. doi: $10.1177 / 0309133320960670$

Larson, E. R., Kipfmueller, K. F., and Johnson, L. B. (2021b). People, fire, and pine: linking human agency and landscape in the boundary waters canoe area wilderness and beyond. Ann. Am. Assoc. Geogr. 111, 1-25. doi: 10.1080/24694452.2020.1768042

Magruder, M., Chhin, S., Palik, B., and Bradford, J. B. (2013). Thinning increases climatic resilience of red pine. Can. J. For. Res. 43, 878-889. doi: 10.1139/cjfr-2013-0088

Maxwell, J. T., Harley, G. L., Matheus, T. J., Strange, B. M., Van Aken, K., Fung $\mathrm{Au}, \mathrm{T}$., et al. (2020). Sampling density and date along with species selection influence spatial representation of tree-ring reconstructions. Climate Past 16, 1901-1916. doi: 10.5194/cp-16-1901-2020

Maxwell, J. T., Harley, G. L., and Robeson, S. M. (2016). On the declining relationship between tree growth and climate in the Midwest United States: the fading drought signal. Climat. Change 138, 127-142. doi: 10.1007/s10584-016-1720-3

Maxwell, R. S., Belmecheri, S., Taylor, A. H., Davis, K. J., and Ocheltree, T. W. (2020). Carbon isotope ratios in tree rings respond differently to climatic variations than tree-ring width in a mesic temperate forest. Agric. For. Meteorol. 288-289:108014. doi: 10.1016/j.agrformet.2020.108014

Meko, D., Cook, E. R., Stahle, D. W., Stockton, C. W., and Hughes, M. K. (1993). Spatial patterns of tree-growth anomalies in the United States and Southeastern Canada. J. Clim. 6, 1773-1786. doi: 10.1175/1520-0442(1993)006<1773:SPOTGA > 2.0.CO;2

Menne, M. J., Durre, I., Vose, R. S., Gleason, B. E., and Houston, T. G. (2012). An overview of the global historical climatology network-daily database. J. Atmos. Ocean. Technol. 29, 897-910. doi: 10.1175/JTECH-D-11-00103.1

Moser, L., Fonti, P., Büntgen, U., Esper, J., Luterbacher, J., Franzen, J., et al. (2010). Timing and duration of European larch growing season along altitudinal gradients in the Swiss Alps. Tree Physiol. 30, 225-233. doi: $10.1093 /$ treephys/tpp108

R Core Team (2020). R: A Language and Environment for Statistical Computing. Vienna: R Foundation for Statistical Computing. Available online at: https:// www.R-project.org/ (accessed September 20, 2021).

Robeson, S. M. (2002). Increasing Growing-Season Length in Illinois during the 20th Century. Climat Change 52, 219-238. doi: 10.1023/A.:10130880 11223

Simolo, C., Brunetti, M., Maugeri, M., and Nanni, T. (2010). Improving estimation of missing values in daily precipitation series by a probability density functionpreserving approach. Int. J. Climatol. 30, 1564-1576. doi: 10.1002/joc.1992

Skaggs, R. H., and Baker, D. G. (1985). Fluctuations in the length of the growing season in Minnesota. Clim. Change 7, 403-414. doi: 10.1007/BF001 39055

Stahle, D. W., Cook, E. R., Burnette, D. J., Torbenson, M. C. A., Howard, I. M., Griffin, D., et al. (2020). Dynamics, variability, and change in seasonal precipitation reconstructions for North America. J. Clim. 33, 3173-3195. doi: 10.1175/JCLI-D-19-0270.1

St. George, S., Meko, D. M., and Cook, E. R. (2010). The seasonality of precipitation signals embedded within the North American Drought Atlas. Holocene 20, 983-988. doi: 10.1177/0959683610365937 
St. George, S., Meko, D. M., Girardin, M. P., MacDonald, G. M., Nielsen, E., Pederson, G. T., et al. (2009). The tree-ring record of drought on the Canadian Prairies. J. Clim. 22, 689-710. doi: 10.1175/2008JCLI2441.1

Stokes, M. A., and Smiley, T. L. (1996). An Introduction to Tree-Ring Dating. Chicago, IL: Univ. of Chicago Press.

Torbenson, M. C. A., Stahle, D. W., Villanueva Díaz, J., Cook, E. R., and Griffin, D. (2016). The relationship between earlywood and latewood ring-growth across North America. Tree Ring Res. 72, 53-66. doi: 10.3959/1536-1098-72.02.53

Trewartha, G. T. (1981). The bimodal warm season precipitation profile of the upper Middle West. Ann. Assoc. Am. Geogr. 71, 566-571. doi: 10.1111/j.1467-8306.1981.tb01375.x

Vaganov, E. A., Hughes, M. K., Kirdyanov, A. V., Schweingruber, F. H., and Silkin, P. P. (1999). Influence of snowfall and melt timing on tree growth in subarctic Eurasia. Nature 400, 149-151. doi: 10.1038/22087

Visser, H., and Molenaar, J. (1988). Kalman filter analysis in dendroclimatology. Biometrics 44:929. doi: 10.2307/2531724

Vose, R. S., Applequist, S., Squires, M., Durre, I., Menne, C. J., Williams, C. N., et al. (2014). Improved historical temperature and precipitation time series for U.S. climate divisions. J. Appl. Meteorol. Climatol. 53, 1232-1251. doi: 10.1175/JAMC-D-13-0248.1

Watson, E., and Luckman, B. H. (2016). An investigation of the snowpack signal in moisture-sensitive trees from the Southern Canadian Cordillera. Dendrochronologia 38, 118-130. doi: 10.1016/j.dendro.2016.03.008

Webb, S. L., Marty, B. S., and Conklin, P. S. (2001). Forest Changes Due to Prescribed Burns and Windstorms in Itasca State Park, Minnesota: A Preliminary
Report. Saint Paul, MN: Minnesota Department of Natural Resources, Division of Ecological Sciences.

Wilmking, M., Maaten-Theunissen, M., van der, Maaten, E., van der, Scharnweber, T., Buras, A., Biermann, C., et al. (2020). Global assessment of relationships between climate and tree growth. Glob. Chang. Biol. 26, 3212-3220. doi: $10.1111 /$ gcb.15057

Conflict of Interest: The authors declare that the research was conducted in the absence of any commercial or financial relationships that could be construed as a potential conflict of interest.

Publisher's Note: All claims expressed in this article are solely those of the authors and do not necessarily represent those of their affiliated organizations, or those of the publisher, the editors and the reviewers. Any product that may be evaluated in this article, or claim that may be made by its manufacturer, is not guaranteed or endorsed by the publisher.

Copyright (c) 2022 Trumper, Griffin, Montpellier and Kipfmueller. This is an openaccess article distributed under the terms of the Creative Commons Attribution License (CC BY). The use, distribution or reproduction in other forums is permitted, provided the original author(s) and the copyright owner(s) are credited and that the original publication in this journal is cited, in accordance with accepted academic practice. No use, distribution or reproduction is permitted which does not comply with these terms. 